\title{
CORYPHÆNA PENTADACTYLA.
}

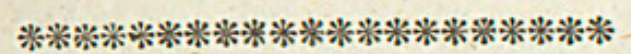

CHARACTER GENERICUS.

Caput maxime truncato-declive. Membr. branch. radiis quinque. Pinna dorsalis longitudine dorsi.

CHARACTER SPECIFICUS, छc.

Coryphæna quinque-maculata. - C. subfusca,

- subtus argentea, maculis utrinque versus caput quinque nigris.

Gen. Zool. 4. p. 218.

Coryphæna pentadactyla. C. maculis quinis nigris versus caput longitudinalibus.

Lyn. Syst. Nat.

Coryphæna cauda æquali, pinnæ dorsi radiis 21 . Bloch. ichth. t. 173.

In maribus Indicis innascitur Coryphæna pentadactyla, in pedalem vel sesquipedalem crescens longitudinem. 


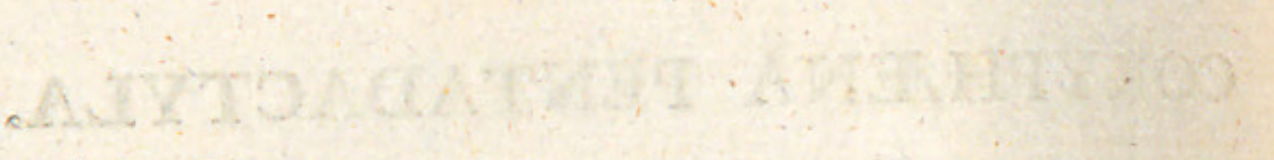





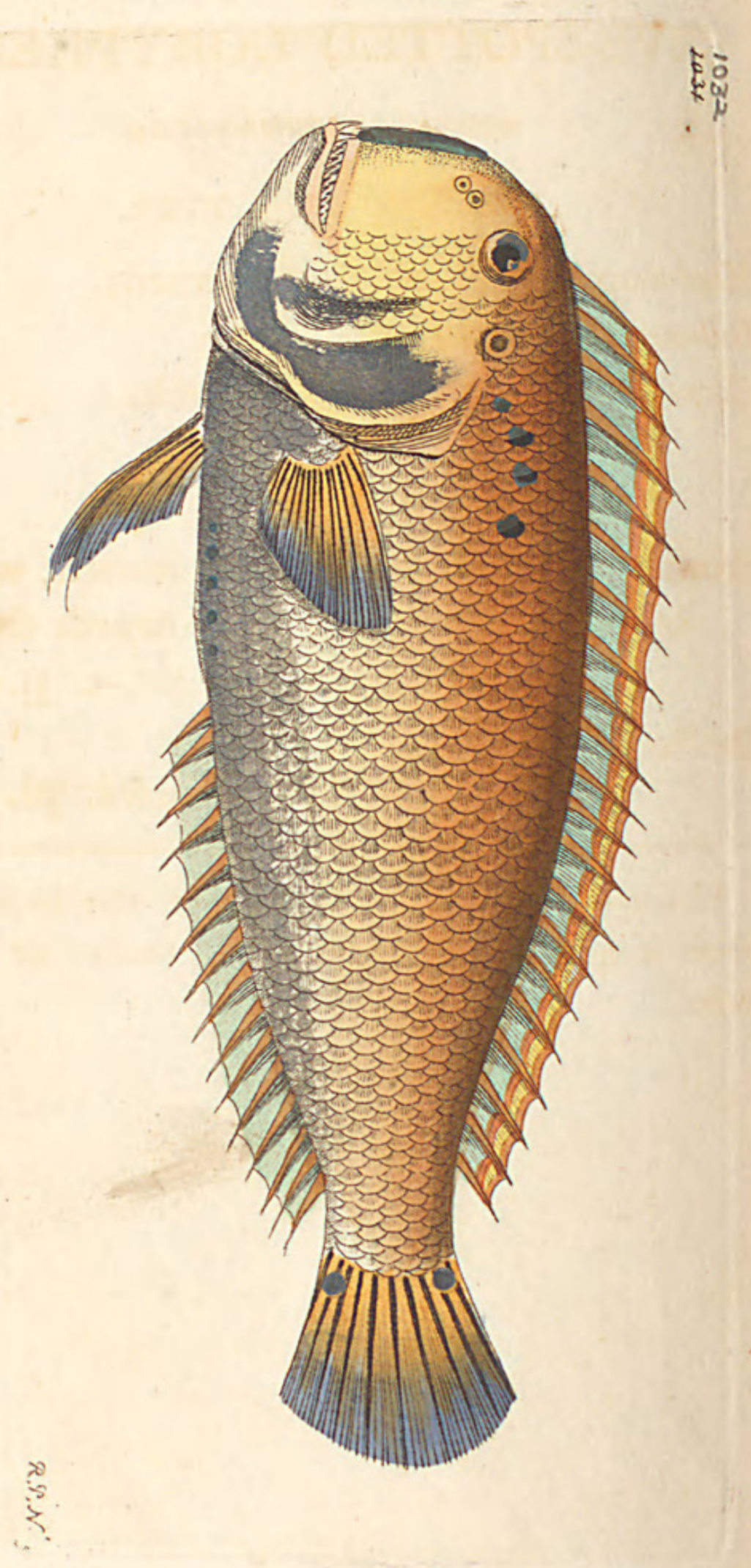




\section{FIVE-SPOTTED CORYPHENE.}

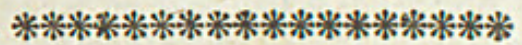

GENERIC CHARACTER.

Head sloping suddenly downwards. Gill-membrane five-rayed.

Dorsal fin the length of the back.

SPECIFIC CHARACTER, छ`c.

Brownish Coryphene, silvery beneath, with five black spots on each side towards the head. Gen. Zool. 4. p. 218.

Das Sechsauge.

Bloch. ichth. pl. 173.

This species is an inhabitant of the Indian seas, where it grows to the length of twelve or eighteen inches. 


\section{$2 \mathrm{BHL}$ Biodiversity Heritage Library}

Shaw, George. 1812. "Coryphæna pentadactyla, The Five-spotted Coryphene [PI. 1032]." The Naturalist's Miscellany 24(CCLXXIX), -.

https://doi.org/10.5962/p.322312.

View This Item Online: https://www.biodiversitylibrary.org/item/296719

DOI: https://doi.org/10.5962/p.322312

Permalink: https://www.biodiversitylibrary.org/partpdf/322312

\section{Holding Institution}

Museums Victoria

\section{Sponsored by}

Atlas of Living Australia

\section{Copyright \& Reuse}

Copyright Status: Public domain. The BHL considers that this work is no longer under copyright protection.

This document was created from content at the Biodiversity Heritage Library, the world's largest open access digital library for biodiversity literature and archives. Visit BHL at https://www.biodiversitylibrary.org. 